\title{
Aplikasi Sensor Cahaya Sebagai Sensor Garis Pada Robot Berbasis Kontrol PID Dengan Pengaturan Kepekaan Cahaya Otomatis
}

\author{
I Made Niantara Riandana ${ }^{1}$, I Nyoman Budiastra ${ }^{2}$, Cok Gede Indra Partha ${ }^{3}$
}

\begin{abstract}
Line follower robot requires an automatic control system in operating to follow a track / line. Control systems are used in line follower robot is PID-based control system. In PID control system requires setting of constants $\mathrm{Kp}, \mathrm{Kd}$, and $\mathrm{Ki}$ proper to obtain a stable movement of the robot to follow the line or track. Line follower robot that used in this research is an adaptive robot, so the robot can adapt in every lighting conditions were be different on each track by adding two pieces of light sensors on the robot.

The integration of the PID control system by setting the constants of $\mathrm{Kp}, \mathrm{Kd}$, Ki precise and automatic light sensitivity settings, will produce good movement to follow the track and that can adapt with every lighting conditions automatically be. From the experiment have been done, obtained the best control constants of $\mathrm{Kp}, \mathrm{Kd}$, and $\mathrm{Ki}$ with a constant value entered is $K p=7, K d=5$, and $K i=7$ and light sensitivity automatic setting searched based on a reading of two light sensors and with the formula of sensitivity is $=(($ sensor $1+$ sensor 2$) / 2)+100$.
\end{abstract}

Intisari-Robot line followermerupakan robot dengan sistem kontrol otomatis dalam beroprasi mengikuti sebuah lintasan/garis. Sistem kontrol yang digunakan dalam robot line follower adalah sistem kontrol berbasis PID. Pada sistem kontrol PID memerlukan pengaturan konstanta Kp, Kd, dan Ki yang tepat untuk memperolehpergerakan robot yang stabil dalam mengikuti garis atau lintasan. Robot line follower yang digunakan pada penelitian ini adalah robot yang bersifat adaptif, sehingga robot dapat beradaptasi di setiap kondisi pencahayaan yang berbeda pada setiap lintasan dengan memanfaatkan penambahan 2 buah sensor cahaya pada robot.

Hasil daripenggabungan sistem pengaturan PID dengan pengaturan konstanta Kp, Kd dan Ki yang tepat dan sistem pengaturan kepekaan cahaya otomatis, maka akan diperoleh hasil pergerakan robot pada lintasan yang baik dan robot yang dapat beradaptasi dalam beberapa kondisi pencahayaan secara otomatis. Dari hasil ujicoba robot yang telah dilakukan, maka telah diperoleh pengaturan konstanta Kp, Kd, dan Ki terbaik dengan nilai kons

${ }^{1}$ Mahasiswa, Jurusan Teknik Elektro dan Komputer Fakultas TeknikUniversitas Udayana, Jln. Kampus Bukit Jimbaran 80361 INDONESIA (telp: 0361-703315; fax: 0361-4321; e-mail: niantarariandana@yahoo.co.id

${ }^{2,3}$ Dosen, Jurusan Teknik Elektro dan Komputer Fakultas TeknikUniversitas Udayana, Jln. Kampus Bukit Jimbaran 80361 INDONESIA (telp: 0361-703315; fax: 0361-4321; e-mail: ²budiastra@ee.unud.ac.id, ${ }^{3}$ cokindra@unud.ac.id, tanta yang diinputkan yaitu $K p=7, K d=5$, dan $K i=7$ dan pengaturan kepekaan cahaya otomatis yang dicari berdasarkan pembacaan 2 buah sensor cahaya dan dengan rumus kepekaan = $((\operatorname{sensor} 1+\operatorname{sensor} 2) / 2)+100$.

Kata Kunci-Robot, PID, Cahaya, Kepekaan, Garis, Sensor.

\section{PENDAHULUAN}

Perkembangan teknologi pada saat ini berkembang sangat pesat. Salah satunya adalah dalam dunia robotika dengan sistem kontrol otomatis. Robot yang banyak dijumpai saat ini adalah robot line follower atau robot pengikut garis. Perkembangan teknologi ini, menuntut pula pengembangan dari sistem otomatisasi dalam sistem robotika yang semakin meningkat dan handal. Karena dengan peningkatan sistem otomatisasi pada dunia robotika ini, akan dapat membuat kinerja dari robot untuk lebih dioptimalkan dalam segi penggunaannya.

Pemanfaatan robot line follower ini telah banyak dikembangkan dalam pengaplikasiannya, seperti sebagai robot pengantar surat di area kantor, serta robot pengantar makanan di restaurant. Namun dalam pengaplikasiannya, robot line follower masih terdapat beberapa kekurangan yang harus ditingkatkan. Permasalahan yang ada seperti sistem kontrol yang masih belum optimal dan robot masih dapat terganggu sistem kerjanya oleh cahaya luar .

Sehingga untuk mendapatkan sitem kerja yang optimal pada robot, maka dibutuhkan suatu rangkaian kontroler yang dapat membuat pergerakan robot yang stabil dan presisi didalam mengikuti lintasan / garis. Rangkaian kontrol yang umum digunakan adalah rangkaian kontroler berbasis PID (Proportional-Integral-Derivative). Dalam sistem control berbasis PID diperlukan penginputan nilai konstanta parameter proporsional $\left(\mathrm{K}_{\mathrm{p}}\right)$, intregral $\left(\mathrm{K}_{\mathrm{i}}\right)$, dan derivative $\left(\mathrm{K}_{\mathrm{d}}\right)$ [1][2]. Sedangkan untuk permasalahan kinerja robot terhadap pengaruh dari cahaya luar pada lintasan, maka diperlukannya suatu pengaturan kepekaan cahaya otomatis yang dapat membuat robot dapat beradaptasi dengan lingkungan kerjanya.

\section{APLIKASI SENSOR CAHAYA SEBAGAI SENSOR GARIS}

Prinsip kerja dari sensor cahaya sebagai sensor garis pada robot adalah dengan memanfaatkan adanya perbedaan warna antara garis/jalur dengan background[3]. 


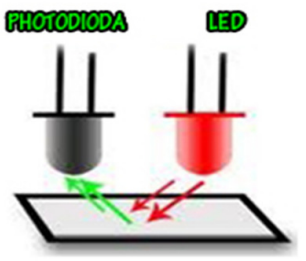

Sensor Pada Warna Putih Gambar 1 Prinsip Kerja

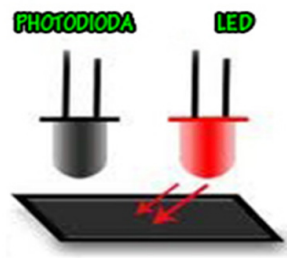

Sensor Pada Warna Hitam n Rangkaian Sensor Garis
Rangkaian sensor garis terdiri dari 2 bagian, yaitu bagian pemancar cahaya (LED) dan bagian penerima cahaya (photodiode). Sedangkan selanjutnya setelah komponen photodiode menerima pancaran cahaya dari LED selanjutnya rangkaian komparator akan membandingkan tegangan input dari sensor dengan tegangan referensi untuk menghasilkan logika biner 0 dan 1 untuk membedakan antara pantulan cahaya yang mengenai garis hitam dan cahaya yang memantul pada background berwarna putih pada lintasan.

Dari hasil perbedaan intensitas pantulan cahaya yang diterima photodiode pada keseluruhan sensor yang digunakan ini, selanjutnya akan dirubah menjadi suatu nilai-nilai yang merepresentasikan rangkaian logika biner. Rangkaian logika biner inilah yang nantinya akan digunakan sebagai parameter dalam menentukan pergerakan dari robot [4].

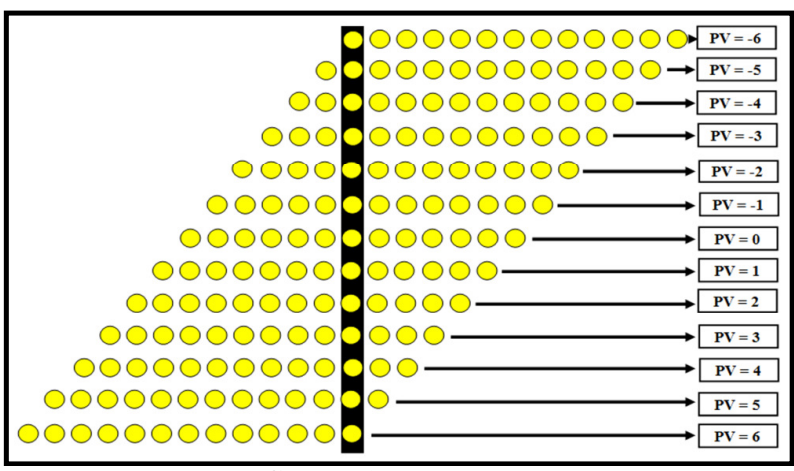

Gambar 2 Logika Sensor

Dapat dilihat pada gambar 2, dimana pada sensor tersebut menggunakan 13 buah sensor cahaya. Pada gambar tersebut digambarkan pemberian nilai yang diasumsikan sebagai process variable (PV) dari beberapa kondisi sensor. Nilai dari PV dibuat bernilai positif dan negatif dimaksudkan untuk mempermudah didalam perhitungan pengontrolan putaran motor dari robot. Kondisi PV $=0$ berarti posisi dari garis tepat berada pada tengah sensor yang merupakan posisi ideal untuk pergerakan robot maju kedepan dengan menghasilkan putaran motor kanan dan kiri robot berputar dengan kecepatan putaran yang sama.

\section{KONTROL PID}

Kontrol PID merupakan gabungan antara pengendali proposional, pengendali integral, dan pengendali derivativ [5][2]. PID (Proporsional Integral Derivativ) adalah sebuah sistem kontrol yang digunakan untuk menentukan sistem kontrol yang presisi pada suatu sistem instrumental dengan memiliki karakteristik berupa umpan balik (feedback) pada sistemnya [6].

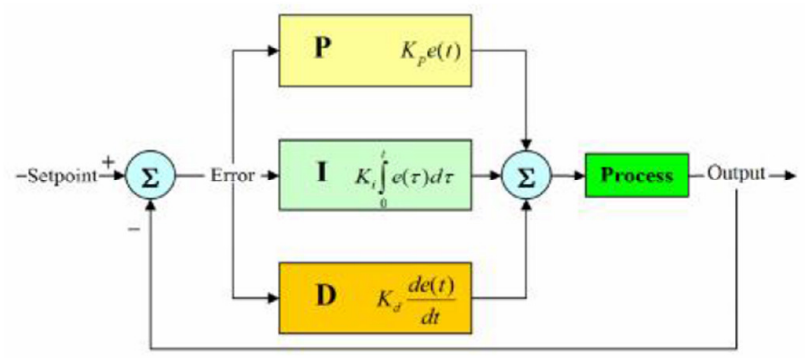

Gambar 3 Blok Diagram Kontrol PID

Nilai error (e) dalam rumus tersebut diperoleh dengan menggunakan rumus :

$$
\text { Error }=\text { Setpoint }- \text { Process Variable }
$$

Dengan :

Setpoint $(\mathrm{SP}) \quad=$ merupakan nilai tujuan yang ingin dipenuhi.

Process Variable $(\mathrm{PV})=$ nilai sensor garis yang terkena garis hitam (lintasan ).

a) Proporsional

Rumus dasar dari sistem kontroler proporsional adalah :

$$
\mathrm{P}=\mathrm{Kp} \times \mathrm{e}(\mathrm{t})
$$

Dengan :

$$
\begin{aligned}
& \mathrm{P}=\text { proporsional } \\
& \mathrm{Kp}=\text { nilai konstanta proporsional } \\
& \mathrm{e}(\mathrm{t})=\text { nilai eror yang akan selalu berubah }- \text { ubah }
\end{aligned}
$$

Seperti yang dijelaskan pada dasar teori sistem kontrol berbasis PID, bahwa nilai error diperoleh dari rumus : Setpoint - Process Variable. Sehingga jika dirubah kedalam sintak program maka menjadi [6]:

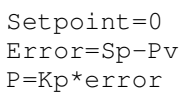

b) Integral

Rumus dasar dari sistem kontroler integral adalah:

$$
\mathrm{I}=\mathrm{Ki} \int_{0}^{t} e(t) d t
$$

Dengan:

$$
\begin{aligned}
& \mathrm{I}=\text { integral } \\
& \mathrm{Ki}=\text { nilai konstanta integral } \\
& \mathrm{e}(\mathrm{t})=\text { nilai error } \\
& \mathrm{dt}=\text { nilai perubahan waktu (second) }
\end{aligned}
$$

Pengaturan sistem kontroler integral tidak dapat digunakan sendiri, sehingga harus digabungkan dengan kontroler proporsional. Jika dirubah kedalam bentuk sintak program maka menjadi [6]: 


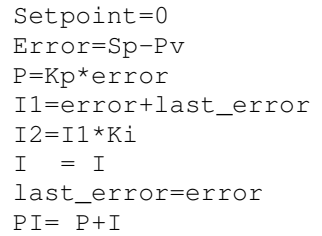

c) Derivativ

Rumus dasar dari sistem kontroler derivativ adalah:

$$
\mathrm{D}=\mathrm{Kd} \frac{d e(t)}{d t}
$$
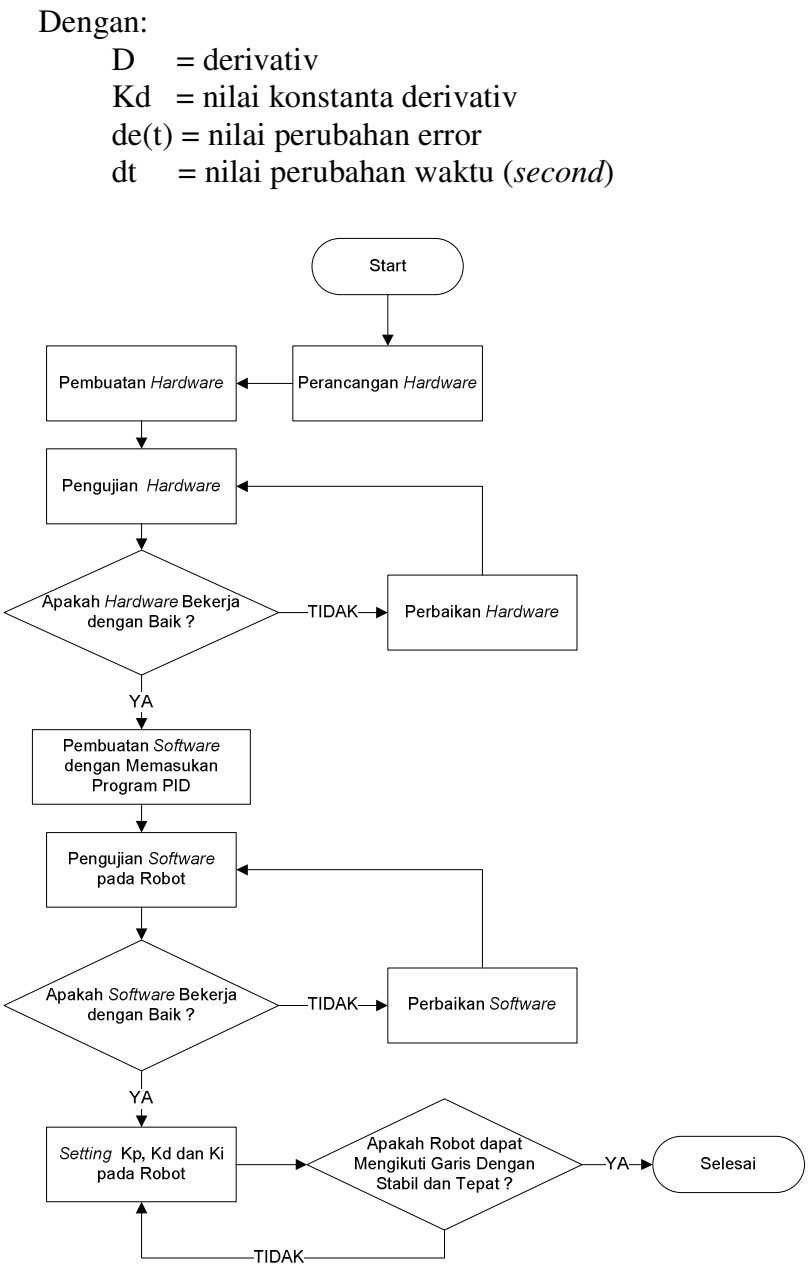

Gambar 4 Diagram Alir Prosedur Penelitian Pencarian Pengaturan Konstanta PID

Sama halnya dengan sistem kontroler Integral, kontroler Derivativ juga tidak dapat digunakan sendirian, melainkan juga harus digabungkan dengan kontroler Proporsional. Apabila tidak, kontroler Derivativ tidak akan dapat melakukan aksi apapun, karena tidak ada perubahan dari nilai error. Jika dirubah kedalam sintak program maka menjadi [6]:

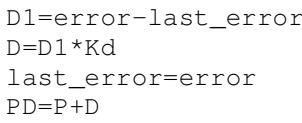

Jadi setelah ketiga kontroler tersebut digabungkan, maka sintak programnya menjadi [6]:

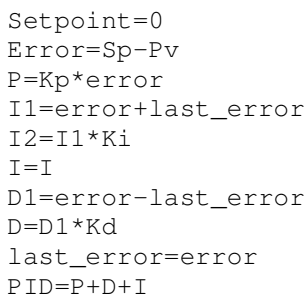

\section{PENGATURAN KePEKAAN CAHAYA OTOMATIS}

\section{A. Pengaturan Kepekaan Cahaya}

Pengaturan kepekaan cahaya pada robot line follower adalah pengaturan nilai parameter pada mikrokontroller untuk memudahkan mikrokontroler untuk menggolongkan nilai inputan sensor cahaya (nilai ADC) merupakan nilai dari pantulan cahaya yang mengenai garis (hitam) atau pantulan cahaya yang megenai background lintasan (putih). Pengaturan kepekaan cahaya ini sangat penting dalam membuat pergerakan dari robot line follower yang stabil dan berakurasi tinggi. Sistem kerjanya dapat diumpamakan sebagai berikut :

a. Pembacaan nilai ADC sensor berkisar dari 0-1023.

b. Nilai Kepekaan cahaya yang diinputkan diumpamakan adalah 350 .

nilai sensor cahaya $<$ dari nilai kepekaan $(350)=$ warna putih

nilai sensor cahaya $>$ dari nilai kepekaan $(350)=$ warna hitam

Secara sederhana konsep dari penginputan kepekaan cahaya adalah seperti dijelaskan tersebut. Kondisi pembacaan terbaik untuk sensor cahaya ketika cahaya memantul pada garis berwarna hitam adalah mendapatkan nilai ADC : 1023.

\section{B. Perancangan Sistem Pengaturan Kepekaan Cahaya Otomatis}

Perancangan sitem pengaturan kepekaan cahaya otomatis ini, dirancang dengan memasang 2 buah sensor cahaya tambahan dan pada masing-masing sensornya disinari oleh 2 buah LED. 2 buah sensor ini digunakan sebagai sensor untuk menentukan nilai kepekaan cahaya yang akan diatur selama robot beroprasi. Tujuan dari dipasangnya 2 LED untuk 1 sensor cahaya adalah agar nilai yang didapatkan dari sensor cahaya ini tidak terganggu saat salah satu LED yang menyinarinya terkena garis/lintasan. 2 buah sensor ini diletakan didepan dari 13 sensor cahaya yang berfungsi untuk mendeteksi garis seperti yang ditunjukan pada gambar 4 berikut :

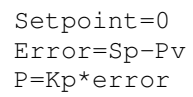

ISSN 1693-2951I Made Niantara Riandana : Aplikasi Sensor Cahaya sebagai Sensor Garis ... 


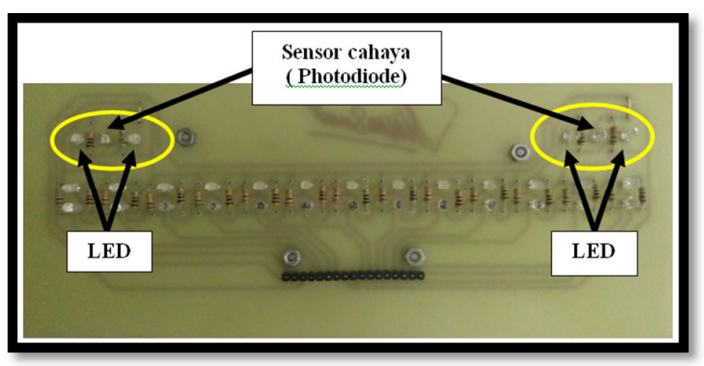

Gambar 5 Posisi Sensor Cahaya Sebagai Sensor Pengatur Kepekaan Cahaya Otomatis

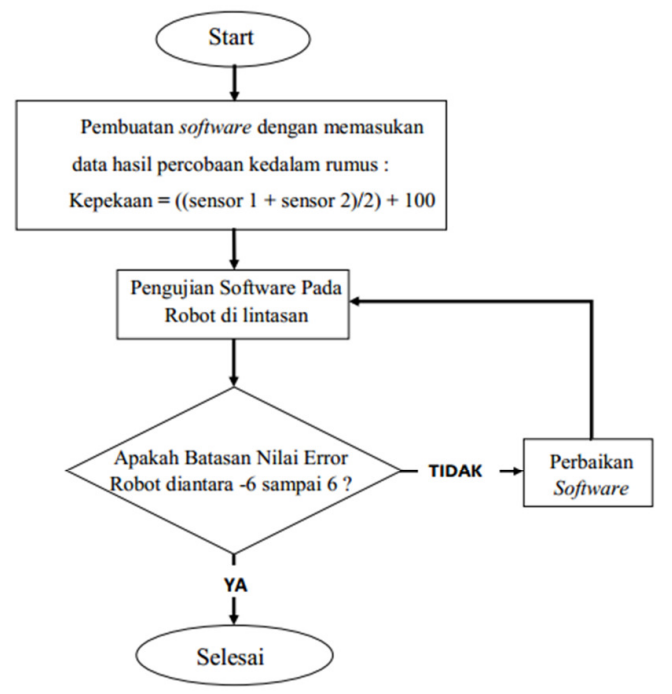

Gambar 6 Diagram Alir Sistem Kepekaan Cahaya Otomatis

\section{HASIl PENGUJiAn Sistem PID dAN PENGATURAN KEPEKAAN CAHAYA OTOMATIS PADA ROBOT}

A. Pengujian Sistem Kontrol PID

Berikut merupakan hasil pengujian dari sistem kontrol PID yang telah dilakukan dengan cara menganalisa hasil dari pergerakan robot dalam mengikuti lintasan yang telah disediakan. Adapun robot dan lintasan yang digunakan dalam pengujian adalah sebagai berikut :

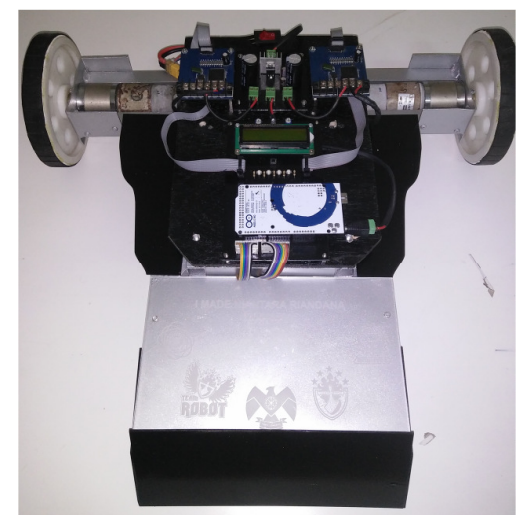

Gambar 7 Robot Line Follower yang digunakan

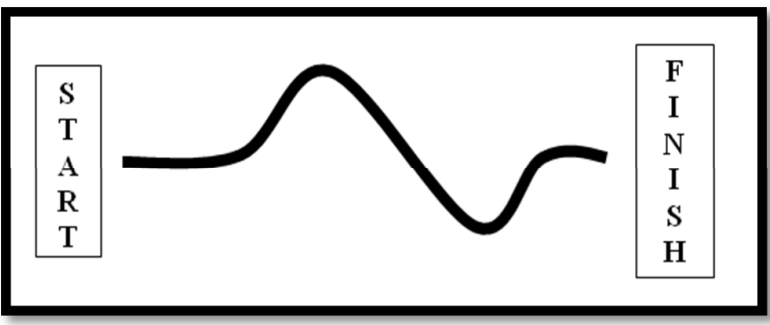

Gambar 8 Lintasan Pengujian Pergerakan Sistem PID

Dari hasil percobaan dengan mengatur variasi nilai konstanta P, I, D pada robot dalam mengikuti lintasan, maka didapatkan hasil terbaik pergerakan robot dengan pengaturan nilai konstanta $\mathrm{Kp}, \mathrm{Kd}$, Ki seperti yang ditunjukan pada tabel berikut :

TABEL I

HaSil PENGUJIAN PERGERAKAN RoBot TERBAIK DENGAN PENGATURAN KP, KD $D A N K I$

\begin{tabular}{|c|c|c|c|c|c|}
\hline \multirow{2}{*}{ No } & \multicolumn{3}{|c|}{ Input } & \multirow{2}{*}{ Error } & Hasil \\
\cline { 2 - 5 } & $\mathrm{Kp}$ & $\mathrm{Kd}$ & $\mathrm{Ki}$ & & \\
\hline 1 & 7 & 5 & 7 & -5 sampai 4 & Sangat Baik \\
\hline 2 & 7 & 4 & 6 & -5 sampai 5 & Sangat Baik \\
\hline 3 & 7 & 3 & 7 & -5 sampai 5 & Sangat Baik \\
\hline 4 & 7 & 5 & 6 & -5 sampai 5 & Sangat Baik \\
\hline 5 & 7 & 3 & 5 & -5 sampai 5 & Sangat Baik \\
\hline 6 & 7 & 3 & 8 & -5 sampai 5 & Sangat Baik \\
\hline 7 & 7 & 3 & 6 & -5 sampai 5 & Sangat Baik \\
\hline 8 & 7 & 3 & 4 & -6 sampai 6 & Baik \\
\hline 9 & 7 & 3 & 3 & -6 sampai 6 & Baik \\
\hline 10 & 6 & 5 & 4 & -6 sampai 6 & Baik \\
\hline
\end{tabular}

Keterangan :

a. Sangat Baik $=$ Nilai error diantara -5 sampai dengan $5(-5 \geq$ error $\leq 5)$

b. Baik = Nilai error diantara -6 sampai dengan

I Made Niantara Riandana : Aplikasi Sensor Cahaya sebagai Sensor Garis ... 
$6(-6 \geq$ error $\leq 6)$

c. Cukup Baik = Nilai error lebih besar dari -6 sampai 6 tetapi pergerakan tetap stabil pada lintasan.

d. Buruk $=$ Nilai error lebih besar dari -6 sampai 6 tetapi pergerakan Cukup melebar pada lintasan.

e. $\quad$ Sangat Buruk $=$ Nilai error lebih besar dari -6 sampai 6 dan robot tidak dapat mengikuti lintasan.

f. Nilai error didapat dari rumus error $=$ Set Point $(\mathrm{SP})$ Process Variable (Pv)

Dimana :

$\mathrm{SP}=0$ (merupakan nilai tujuan yang ingin dipenuhi)

$\mathrm{Pv}=$ nilai sensor garis yang terkena garis hitam (lintasan ).

B. Pengujian Pengaruh Cahaya Pada Lintasan Terhadap Pembacaan Sensor

Dari hasil pengujian pengaruh cahaya pada lintasan terhadap pembacaan sensor cahaya, maka akan digunakan untuk menentukan nilai pengaturan kepekaan cahaya yang baik digunakan untuk robot di setiap kondisi pencahayaan yang ada. Cahaya pada lintasan dibuat berubah-ubah memanfaatkan penggunaan sinar lampu dari lampu neon TL 18 watt.

TABEL II

HASIL PENGUJIAN PENGARUH CAHAYA PADA LINTASAN TERHADAP PEMBACAAN SENSOR CAHAYA

\begin{tabular}{|c|c|c|c|c|c|c|}
\hline \multirow{2}{*}{ No } & $\begin{array}{c}\text { Cahaya } \\
\text { Pada } \\
\text { Lintasan } \\
\text { (LUX) }\end{array}$ & \multicolumn{2}{|c|}{$\begin{array}{c}\text { Sensor Garis } \\
\text { (ADC) }\end{array}$} & \multicolumn{2}{|c|}{$\begin{array}{c}\text { Sensor Garis } \\
\text { (ADC) }\end{array}$} & $\begin{array}{c}\text { Pengaturan Kepekaan } \\
(\text { (Sensor1+Sensor2)/2) } \\
+100\end{array}$ \\
\cline { 3 - 7 } & Puth & Hitam & $\begin{array}{c}\text { Sensor } \\
1\end{array}$ & $\begin{array}{c}\text { Sensor } \\
2\end{array}$ & \\
\hline 2 & 50 & 232 & 1023 & 200 & 210 & 305 \\
\hline 3 & 140 & 233 & 1023 & 205 & 213 & 309 \\
\hline 4 & 200 & 240 & 998 & 237 & 240 & 337.5 \\
\hline 5 & 220 & 244 & 912 & 239 & 242 & 340.5 \\
\hline 6 & 300 & 252 & 725 & 240 & 245 & 342.5 \\
\hline 7 & 450 & 260 & 500 & 247 & 252 & 349.5 \\
\hline 8 & 700 & 264 & 375 & 251 & 254 & 352.5 \\
\hline
\end{tabular}

Berdasarkan data yang telah diperoleh tersebut, terlihat perubahan nilai ADC sensor garis ketika mendeteksi warna putih dan hitam. Saat sensor mendeteksi warna putih dengan intensitas cahaya yang berubah-ubah terlihat perjadi perubahan nilai ADC yang tidak terlalu besar. Sedangkan ketika sensor mendeteksi garis hitam dengan intensitas cahaya yang berubah-ubah terlihat perubahan nilai ADC yang cukup besar. Perubahan nilai inilah yang menyebabkan diperlukannya pengaturan kepekaan cahaya otomatis yang dapat berubah-ubah disetiap kondisi pencahayaan. Tujuannya adalah untuk tetap menjaga nilai refrensi pencahayaan yang dapat menentukan pantulan cahaya dari led yang ditangkap oleh photodiode merupakan pantulan pada garis (hitam) atau background (putih) lintasan.

Dengan melihat pembacaan dari kedua sensor yang digunakan untuk menentukan nilai kepekaan cahaya tersebut, maka dapat digunakan cara sebagai berikut :

$$
\text { Kepekaan }=((\text { sensor } 1+\text { sensor } 2) / 2)+100
$$

Nilai kepekaan dapat diatur dengan cara menjumlahkan nilai ADC yang dibaca oleh sensor 1 dan sensor 2 . Selanjutnya dicari nilai rata-rata pembacaan sensor dengan cara membagi 2 hasil penjumlahan kedua sensor. Selanjutnya nilai rata-rata pembacaan sensor tersebut dijumlahkan dengan nilai 100. Nilai 100 merupakan nilai yang diambil agar nilai kepekaan tetap dapat berada diantara nilai dari pantulan cahaya background putih dan garis hitam yang dibaca oleh sensor photodiode (nilai adc).

C. Uji Coba Robot dengan Pengaturan Kepekaan Cahaya Secara Manual pada Lintasan yang Memiliki Intensitas Cahaya yang Berbeda

Pengujian robot dilakukan pada lintasan dengan intensitas pencahayaan 75 lux serta pada lintasan yang memiliki intensitas pencahayaan 313 lux dengan memanfaatkan penggunaan 2 buah lampu TL Neon 18 watt yang diletakan pada kedua samping lintasan seperti yang terlihat pada gambar 7 dan 8 sebagai berikut :

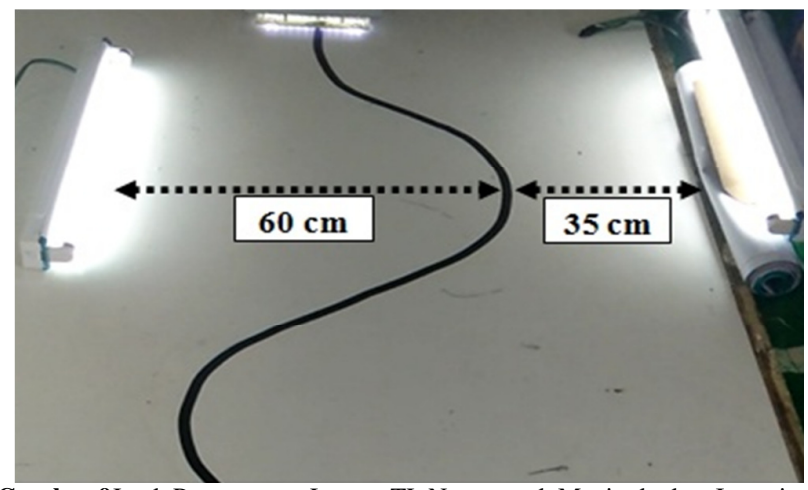

Gambar 9Jarak Pemasangan Lampu TL Neon untuk Meningkatkan Intensitas Cahaya 


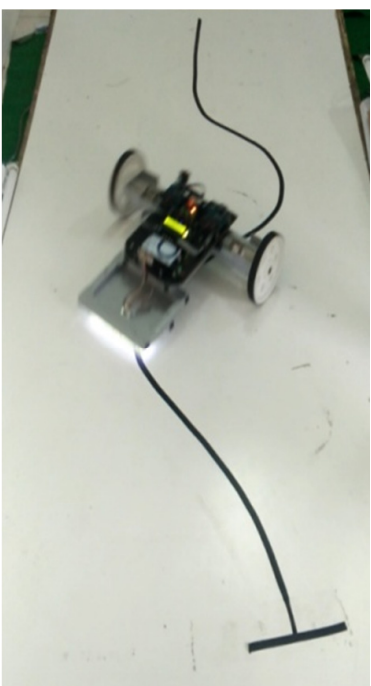

(a)

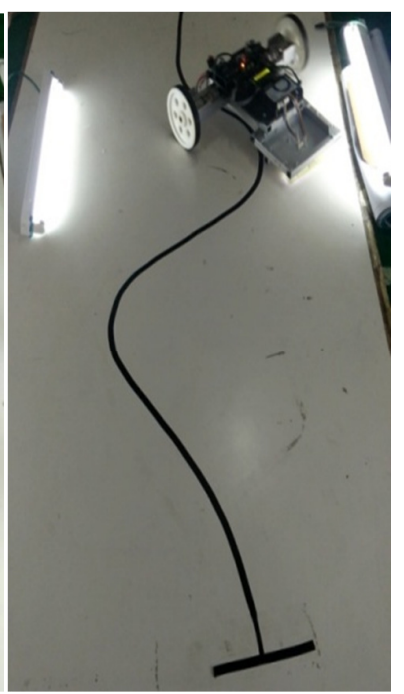

(b)
Gambar 10 (a) Uji Coba Robot Pada Lintasan dengan Intensitas Pencahayaan 75 Lux

(b) Uji Coba Robot Pada Lintasan dengan Intensitas Pencahayaan 313 Lux

Hasil yang diperoleh dari uji coba robot dengan pengaturan kepekaan cahaya secara manual yaitu sebesar 950 (nilai ADC) pada lintasan adalah sebagai berikut:

a. Pada lintasan dengan tingkat pencahayaan 75 lux, robot dapat bergerak stabil mengikuti garis/lintasan. Dikarenakan nilai pengaturan kepekaan cahaya (nilai ADC) yang diinputkan secara manual masih dapat dijadikan sebagai nilai refrensi untuk menentukan pantulan sinar yang ditangkap oleh photodiode (nilai ADC) merupakan background (putih) atau garis (hitam) sehingga robot dapat bergerak mengikuti lintasan dengan stabil.

b. Pada lintasan dengan tingkat pencahayaan 313 lux yang memanfaatkan penggunaan 2 buah lampu TL Neon 18 watt, pergerakan robot tidak stabil dalam mengikuti garis/lintasan. Dikarenakan oleh adanya perubahan nilai pembacaan sensor Photodiode berupa nilai ADC setelah dipengaruhi oleh cahaya dari luar sensor, sehingga nilai kepekaan cahaya yang diatur secara manual yaitu 950 (nilai ADC) tidak dapat dijadikan sebagai nilai refrensi untuk menentukan pantulan sinar yang ditangkap oleh photodiode merupakan background (putih) atau garis (hitam).

D. Uji Coba Robot dengan Pengaturan Kepekaan Cahaya Otomatis pada Lintasan yang Memiliki Intensitas Cahaya yang Berbeda

Pengujian robot dilakukan pada lintasan dengan intensitas pencahayaan 75 lux serta pada lintasan yang memiliki intensitas pencahayaan 313 lux dengan memanfaatkan penggunaan 2 buah lampu TL Neon 18 watt yang diletakan pada kedua samping lintasan seperti yang terlihat pada gambar 9 sebagai berikut :

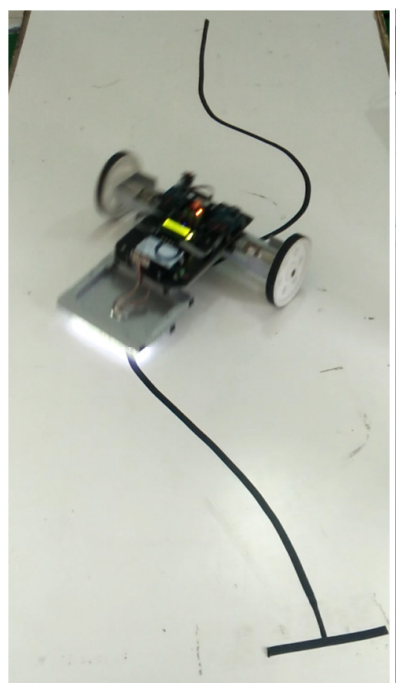

(a)

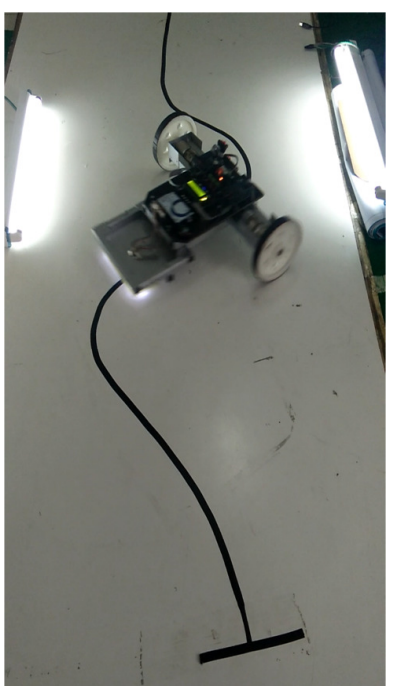

(b)
Gambar 11 (a) Uji Coba Robot Pada Lintasan dengan Intensitas Pencahayaan 75 Lux

(b) Uji Coba Robot Pada Lintasan dengan Intensitas Pencahayaan 313 Lux

Hasil yang diperoleh dari uji coba robot dengan pengaturan kepekaan cahaya secara otomatis pada lintasan adalah sebagai berikut :

a. Pada lintasan dengan tingkat pencahayaan 75 lux, robot dapat bergerak stabil mengikuti garis/lintasan. Dikarenakan nilai pengaturan kepekaan cahaya (nilai ADC) yang diinputkan secara manual masih dapat dijadikan sebagai nilai refrensi untuk menentukan pantulan sinar yang ditangkap oleh photodiode (nilai ADC) merupakan background (putih) atau garis (hitam) sehingga robot dapat bergerak mengikuti lintasan dengan stabil.

b. Pada lintasan dengan tingkat pencahayaannya 313 lux yang memanfaatkan penggunaan 2 buah lampu TL Neon 18 watt, pergerakan robot masih tetap bergerak dengan stabil. Dikarenakan perubahan nilai pembacaan dari sensor photodiode (nilai ADC) setelah dipengaruhi oleh cahaya dari luar sensor, akan berpengaruh juga kepada pengaturan kepekaan cahaya otomatisnya yang menyesuaikan nilai kepekaan yang nantinya dapat dijadikan sebagai nilai refrensi untuk menentukan pantulan sinar yang ditangkap oleh photodiode (nilai ADC) merupakan background (putih) atau garis (hitam) sehingga robot dapat bergerak mengikuti lintasan dengan stabil.

TABEL III

HASIL UJICOBA ROBOT DENGAN PENGATURAN KEPEKAAN CAHAYA MANUAL DAN OTOMATIS PADA LINTASAN DENGAN INTENSITAS CAHAYA 75 LUX DAN 313 LUX 


\begin{tabular}{|c|c|c|c|}
\hline No & $\begin{array}{c}\text { Pengaturan Nilai } \\
\text { Kepekaan Cahaya }\end{array}$ & $\begin{array}{c}\text { Cahaya Pada } \\
\text { Lintasan }\end{array}$ & $\begin{array}{c}\text { Hasil Pergerakan Robot } \\
\text { pada Lintasan }\end{array}$ \\
\hline \multirow{2}{*}{1} & Manual & 75 lux & Baik dan Stabil \\
\cline { 3 - 4 } & \multirow{2}{*}{2} & 313 lux & Tidak Stabil \\
\hline \multirow{2}{*}{ Otomatis } & 75 lux & Baik dan Stabil \\
\cline { 3 - 4 } & & 313 lux & Baik dan Stabil \\
\hline
\end{tabular}

\section{KESIMPULAN}

Dari hasil pembahasan dan pengujian aplikasi sensor cahaya sebagai sensor garis pada robot berbasis kontrol PID dengan pengaturan kepekaan cahaya otomatis yang telah dilakukan maka dapat disimpulkan sebagai berikut :

1. Hasil pengujian yang telah dilakukan didapatkan hasil pergerakan robot terbaik dengan pengaturan nilai konstanta $\mathrm{Kp}, \mathrm{Kd}$ dan $\mathrm{Ki}$ pada robot yaitu $: \mathrm{Kp}=7, \mathrm{Kd}=$ 7 dan $\mathrm{Ki}=5$ dengan nilai error yaitu dari -5 sampai 4 .

2. Pengaturan kepekaan cahaya otomatis untuk beberapa kondisi pencahayaan yang ada dapat diperoleh langsung oleh robot dengan memasukan rumus kepekaan otomatis $=(($ sensor $1+$ sensor 2$) / 2)+100$ pada program.

3. Hasil ujicoba robot dengan pengaturan kepekaan cahaya manual sebesar 950(nilai ADC), mendapatkan hasil pergerakan robot bergerak stabil pada lintasan yang memiliki intensitas pencahayaan 75 lux. Sedangkan pada lintasan dengan intensitas pencahayaan 313 lux, robot bergerak tidak stabil.

4. Hasil ujicoba langsung pada robot dengan pengaturan kepekaan cahaya otomatis yang di ujicoba pada lintasan dengan intensitas pencahayaan yang berbeda (75 lux dan 313 lux), maka didapatkan hasil pergerakan yang memiliki akurasi dan kestabilan robot yang sama baiknya di kedua lintasan dengan intensitas cahaya yang berbeda.

\section{REFERENSI}

[1] Ardana,W. R. 2008. Simulasi Sistem Kontroler Pid untuk Motor Induksi Menggunakan Perangkat Lunak Matlab / Simulink. Teknologi Elektro, Vol. 7 (July - Desember) : 1 - 8.

[2] Widhiada, I. W. 2014. Auto Tuning PID Controller Untuk Mengendalikan Kecepatan DC Servomotor Robot Gripper 5 Jari. Jurnal Energi Dan Manufaktur,Vol. 7(Oktober ) : 3 - 4.

[3] Saputro, G. 2012. Sistem Kontrol Motor Robot Line Follower Berbasis Mikrokontroller Atmega32 Menggunakan Algoritma PID (Proporsional Integral Derivatif).Yogyakarta : jurusan teknik informatika STMIK AMIKOM

[4] Prabowo, Y. 2013. Aplikasi PID pada Robot LineFollower Bebasis Mikrokontroler AT-8535. Arsitron, Vol. 4 No.1 Juni 2013

[5] Rahardjo,P. 2004. Aplikasi Mikrokontroler 80c31 Sebagai Alat Pengendali Motor Dc Magnet Permanen dengan Metode P I D Dan Metode P W M, Teknologi Elektro, Vol. 3 (July - Desember) : 2-6.

[6] Pratama, A. M. 2013. Sistem Kontrol Pergerakan pada Robot Line Follower Berbasis Hybride PID-Fuzzy Logic. CSGTEIS. 1-4.

ISSN 1693-2951I Made Niantara Riandana : Aplikasi Sensor Cahaya sebagai Sensor Garis ... 